\title{
Termiskās apstrādes ietekme uz illītu saturošu Latvijas mālu îpatnējo virsmu
}

\author{
Vitālijs Lakevičs ${ }^{1}$, Olga Kaplinova ${ }^{2}$,Valentīna Stepanova ${ }^{3}$, Inga Dušenkova ${ }^{4}$, Līga Bērziṇa-Cimdiṇa ${ }^{5}$, \\ ${ }^{1-5}$ Rìgas Tehniskā universitāte
}

\begin{abstract}
Kopsavilkums. Darbā eksperimentāli pētīta slāpekḷa gāzes sorbcija uz dabīgiem un termiski apstrādātiem Latvijas mālu paraugiem ar daḷiņu lielumu zem $63 \mu \mathrm{m}$ no četrām atradnēm Tūjas (devona periods), Ceplīši un Pavāru (kvartāra periods) un Strēḷu (juras periods). Mērīta iegūto mālu paraugu īpatnējā virsma. Analizēta termiskās apstrādes ietekme uz mālu paraugu sorbcijas īpašībām. Noskaidrots, ka termiskā apstrāde $300{ }^{\circ} \mathrm{C}$ palielina mālu paraugu īpatnējo virsmu, bet temperatūras paaugstināšana līdz 500 - $900{ }^{\circ} \mathrm{C}$ - samazina, salīdzinot ar termiski neapstrādāto paraugu īpatnējās virsmas lielumiem.
\end{abstract}

Atslēgas vārdi: māli, gāzes sorbcija, termiskā apstrāde, īpatnējā virsma, izoterma.

\section{IEVADS}

Mālu kā sorbentu praktisko pielietojumu ietekmē to īpatnējās virsmas lielums, maksimālais poru tilpums un poru sadalījums pēc to tilpumiem. Ir izstrādātas daudzas īpatnējās virsmas noteikšanas metodes, taču mūsdienās visplašāk izmanto IUPAC ieteikto, kura pamatojas uz gāzu vai tvaiku fizikālās adsorbcijas izotermas analīzi. Eksperimentāli izmēra pētāmā parauga adsorbcijas izotermu. Pielietojot Brunauera, Emetta un Tellera (BET) adsorbcijas izotermas vienādojumu, aprēķina adsorbētas vielas daudzumu monomolekulārā slān̄̄, bet no tā - adsorbenta īpatnējo virsmu [1].

Pēdējos gados Latvijas mālu sorbtīvām īpašībām tiek pievērsta pastiprināta uzmanība un notiek to sistemātiska pētīšana [2,3]. Dabīgo mālu svarīga īpašība ir iespēja tos apstrādāt termiski dažādos temperatūras režīmos [4,5]. Šāda dabīgo mālu apstrāde maina mālu poru tilpumu un īpatnējo virsmu, kas savukārt ietekmē adsorbcijas kapacitāti [6,7]. Pieaugošā interese par termiski apstrādātiem māliem ir saistīta ar nepieciešamību radīt ekoloǵiski nekaitīgus, lētus un efektīvus sorbentus. Darbā [8] pētītas dabīgu un termiski apstrādātu (no 200 līdz $800{ }^{\circ} \mathrm{C}$ ) Suntažu, Lažas, Veldzes un Kupravas atradṇu mālu paraugu izmantošanas iespējas notekūdeņu attīrišsanai. Vislielākā sorbcijas spēja raksturīga Kupravas atradnes māliem, un tas izskaidrots ar mālu mineraloǵisko sastāvu un nelielo piemaisījumu daudzumu. Izteikta doma, ka aktīvais komponents mālu sastāvā ir hidromuskovīts. Mālu kristālkīimiskā struktūra sadalās 550 $600{ }^{0} \mathrm{C}$ temperatūrā, un destrukciju pavada strauja sorbcijas spējas samazināšanās. Veldzes atradnes māli, gan dabiskie, gan $600{ }^{0} \mathrm{C}$ temperatūrā apstrādātie, uzrāda labas sorbcijas īpašības uzṇēmumu "Reaǵents" un "Grindeks" tehnoloǵisko notekūdeņu attīrīšanā. Savukārt Kupravas māli sekmīgi izmantoti Valmieras stikla šķiedras rūpnīcas tehnoloǵisko notekūdeņu attīrīšanā no nejonogēnām virsmaktīvām vielām, ekstrahējamām vielām, naftas produktiem, formaldehīda. Visi pētījumi norāda uz dabīgu un modificētu mālu sorbcijas efektivitāti un to iespēju izmantot tautsaimniecībā.

Dotajā darbā pêtīta termiskās apstrādes ietekme uz illītu saturošu dabīgu un termiski apstrādātu Latvijas mālu paraugu īpatnējo virsmu. Darba rezultāti dod vērtīgu informāciju un papildināta datu bāzi par Latvijas vēl neizpētīto atradņu Tūjas, Ceplīšu, Strēl̦u un Pavāru dabīgu un termiski apstrādātu mālu sorbcijas īpašībām. Praktiskā nozīme ir būvmateriālu un keramisko izstrādājumu ražošanā un arī dabas aizsardzībā.

\section{MATERIĀLI UN METODES}

\section{Pètījuma objekti un to raksturojums}

Par pētījuma objektiem ņemti paraugi no četrām Latvijas atradnēm: Tūja (devona periods), Strēḹi (jūras periods), Ceplīš̄̄ un Pavārī (kvartāra periods).

Mālu paraugu raksturojums un apstrādes temperatūras ir parādītas 1.tabulā.

1.TABULA

MĀLU PARAUGU RAKSTUROJUMS UN APSTRĀDES TEMPERATŪRAS

\begin{tabular}{|c|c|c|c|c|}
\hline \multirow[b]{2}{*}{$\begin{array}{c}\text { Parauga } \\
\text { apzīmējums }\end{array}$} & \multirow[b]{2}{*}{$\begin{array}{c}\text { Mālu } \\
\text { atradne/ } \\
\text { periods }\end{array}$} & \multirow[b]{2}{*}{$\begin{array}{c}\text { Daļin̦u } \\
\text { izmērs, } \\
\mu \mathrm{m}\end{array}$} & \multicolumn{2}{|c|}{ Apstrādes apstākḷi } \\
\hline & & & $\begin{array}{c}\text { Apstrādes } \\
\text { temperatūra, } \\
\mathrm{t}^{0} \mathrm{C}\end{array}$ & $\begin{array}{c}\text { Izturēšanas } \\
\text { laiks, st. }\end{array}$ \\
\hline Tūja & \multirow[t]{5}{*}{ Tūja/devona } & $<63$ & - & - \\
\hline Tūja 300 & & $<63$ & 300 & 1 \\
\hline Tūja 500 & & $<63$ & 500 & 1 \\
\hline Tūja 700 & & $<63$ & 700 & 1 \\
\hline Tūja 900 & & $<63$ & 900 & 1 \\
\hline Strēḷi & \multirow[t]{5}{*}{ Strēḷ/ijuras } & $<63$ & - & - \\
\hline Strēl̦i 300 & & $<63$ & 300 & 1 \\
\hline Strēḷi 500 & & $<63$ & 500 & 1 \\
\hline Strēl̦i 700 & & $<63$ & 700 & 1 \\
\hline Strēḷi 900 & & $<63$ & 900 & 1 \\
\hline Ceplīši & \multirow{5}{*}{$\begin{array}{l}\text { Ceplīši/kvar- } \\
\text { tāra }\end{array}$} & $<63$ & - & - \\
\hline Ceplīši 300 & & $<63$ & 300 & 1 \\
\hline Ceplī̌si 500 & & $<63$ & 500 & 1 \\
\hline Ceplīši 700 & & $<63$ & 700 & 1 \\
\hline Ceplīši 900 & & $<63$ & 900 & 1 \\
\hline Pavāri & \multirow{5}{*}{$\begin{array}{c}\text { Pavāri/kvar- } \\
\text { tāra }\end{array}$} & $<63$ & - & - \\
\hline Pavāri 300 & & $<63$ & 300 & 1 \\
\hline Pavāri 500 & & $<63$ & 500 & 1 \\
\hline Pavāri 700 & & $<63$ & 700 & 1 \\
\hline Pavāri 900 & & $<63$ & 900 & 1 \\
\hline
\end{tabular}


Mālu paraugi tika mehāniski atdalīti no piemaisījumiem un uzbriedināti destilētā ūdenī vienu mēnesi. Pēc tam uzbrieduši māli suspensijas veidā sijāti cauri sietu sistēmai, kur sietu acu izmēri ir no $63 \mu \mathrm{m} \mathrm{līdz} 1000 \mu \mathrm{m}$. Iegūti mālu - aleirītu frakcijas paraugi ar daḷiņu izmēriem zem $63 \mu \mathrm{m}$, kas žāvēti žāvskapī $105^{\circ} \mathrm{C}$ temperatūrā.

Iegūtie mālu paraugi apstrādāti termiski augsttemperatūras krāsn̄̄ „Nabertherm LHT 08/17” 300, 500, 700 un $900{ }^{0} \mathrm{C}$ temperatūrā. Termiski apstrādāto mālu paraugu masa bija ap 2 g. Paraugi karsēti ar pastāvīgu, regulējamo àtrumu $4,3^{\circ} \mathrm{C} / \mathrm{min}$. Paraugu izturēšanas laiks krāsnī maksimālā temperatūrā bija viena stunda. Pēc termiskās apstrādes paraugi tika atdzesēti līdz istabas temperatūrai. Pirms un pēc termiskās apstrādes paraugi tika nosvērti. Paraugu masas izmainas termiskās apstrādes rezultātā parādītas 2. tabulā.

\section{TABULA}

LATVIJAS MĀLU PARAUGU MASAS IZMAIN̦AS TERMISKĀS APSTRĀDES REZULTĀTĀ

\begin{tabular}{|c|c|c|c|}
\hline \multirow[b]{2}{*}{$\begin{array}{c}\text { Parauga } \\
\text { apzīmējums }\end{array}$} & \multirow[b]{2}{*}{$\begin{array}{c}\text { Dal̦iņu } \\
\text { izmērs, } \\
\mu \mathrm{m}\end{array}$} & \multicolumn{2}{|c|}{ Apstrādes apstākḷi } \\
\hline & & $\begin{array}{c}\text { Apstrādes } \\
\text { temperatūra, } \\
\text { t }^{0} \mathrm{C}\end{array}$ & $\begin{array}{c}\text { Parauga } \\
\text { masas } \\
\text { izmaiņas, g }\end{array}$ \\
\hline Tūja300 & $<63$ & 300 & 0,002 \\
\hline Tūja500 & $<63$ & 500 & 0,042 \\
\hline Tūja700 & $<63$ & 700 & 0,009 \\
\hline Tūja900 & $<63$ & 900 & 0,095 \\
\hline Strēl̦i300 & $<63$ & 300 & 0,037 \\
\hline Strēḷi500 & $<63$ & 500 & 0,090 \\
\hline Strēḷi700 & $<63$ & 700 & 0,143 \\
\hline Strēḷi900 & $<63$ & 900 & 0,160 \\
\hline Ceplīši300 & $<63$ & 300 & 0,000 \\
\hline Ceplīši500 & $<63$ & 500 & 0,041 \\
\hline Ceplīši700 & $<63$ & 700 & 0,036 \\
\hline Ceplīši900 & $<63$ & 900 & 0,166 \\
\hline Pavāri300 & $<63$ & 300 & 0,017 \\
\hline Pavāri500 & $<63$ & 500 & 0,027 \\
\hline Pavāri700 & $<63$ & 700 & 0,060 \\
\hline Pavāri900 & $<63$ & 900 & 0,064 \\
\hline
\end{tabular}

No 2. tabulas datiem redzams, palielinoties termiskās apstrādes temperatūrai, palielinās paraugu masas zudumi.

\section{Rentgenstaru pulverdifrakcija (XRD)}

Iegūto mālu paraugu fāžu sastāvu identificēšana un analīze veikta ar „PANalytical X'Pert Pro” rentgendifraktometru, izmantojot $\mathrm{Cu} \mathrm{K \alpha}$ starojumu $(\lambda=1.54 \AA)$ ar detektoru (X' Celerator). Difrakcijas ainā tiek attēlota atstarotā intensitāte atkarībā no detektora leṇksa- 2 teta $(\theta)$. Pirms analīzes pulverveida paraugi saberzti piestā. Kristālisko fāžu identificēšanai izmantoti PDF-2 datu bāzē esošie tīru fāžu rentgendifrakcijas dati no ICDD (International Centre for Diffraction Data), izmantojot datorprogrammas X'Pert HighScore un X'Pert Data Viewer.

\section{Latvijas mālu paraugu īpatnējās virsmas noteikšana}

Paraugu īpatnējā virsma analizēta, izmantojot gāzes sorbcijas sistēmu (Quadrasorb SI-KR/MP, Quantachrome Instruments, ASV) no zemtemperatūras (77 K jeb $\left.196^{\circ} \mathrm{C}\right)$ slāpekḷa fizikālās adsorbcijas-desorbcijas izotermām. Īpatnējās virsmas lielumi iegūti ar BET metodi. Pirms sorbcijas eksperimentiem ap 0,3 g paraugu tika degazēti 3 stundas $300{ }^{\circ} \mathrm{C}$ temperatūrā, vakuumā degazācijas ierīcē Autosorb degasser AD-9, (Quantachrome Instruments, ASV), lai atbrīvotu paraugu virsmu no adsorbētā mitruma un citiem piesārṇojumiem.

\section{REZULTĀTI UN IZVĒRTĒJUMS}

\section{Dabīgo mālu paraugu fāžu sastāvu analīze}

1.attēlā ir parādītas Tūjas, Strēḷu, Ceplīšu un Pavāru mālu paraugu rentgendifraktogrammas, kur ir redzami kvarca, kalcīta, illīta un muskovīta raksturīgie maksimumi, kā arī maksimumi, kas atbilst dzelzs oksīdam Ceplīšu mālu paraugu sastāvā.

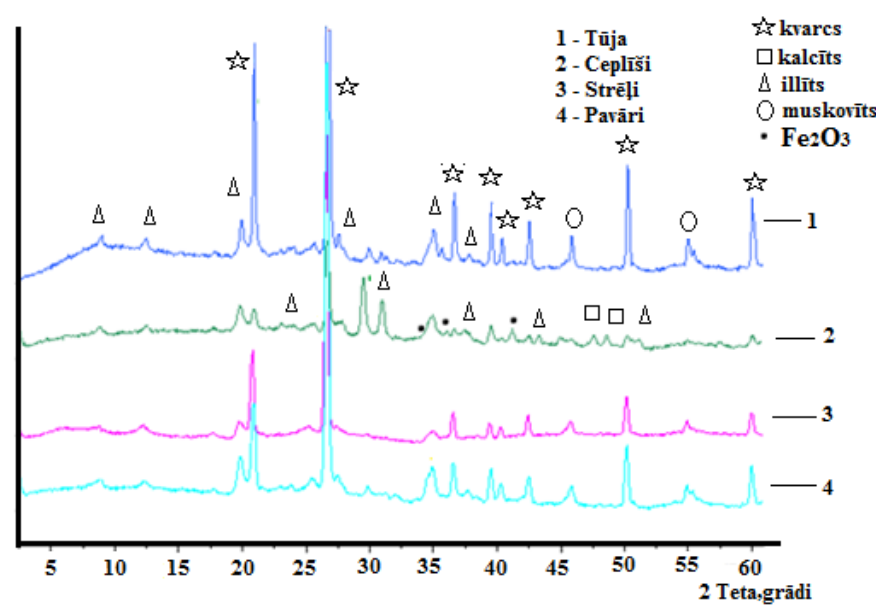

1.att. Tūjas, Strēḷu, Ceplīšu un Pavāru mālu paraugu rentgenogrammas.

Iegūto rentgenogrammu analīze apliecina, ka Latvijas māli pārsvarā ir illītu saturošie māli ar kvarca piejaukumu. Tūjas mālu paraugos ir atrasti arī muskovīta piejaukumi.

Strēḷu mālu paraugos ir arī montmorillonīts, bet tā daudzums ir robežās no 2 līdz 5 procentiem. Tūjas, Strēḷu un Pavāru mālu paraugu rengendifraktometriskie maksimumi ir ļoti līdzīgi, mainās tikai to intensitāte.

Dabīgu un termiski apstrādātu Latvijas mālu paraugu slāpekla gāzes sorbcijas izotermas.

2. attēlā ir parādīta slāpekḷa gāzes adsorbcijas un desorbcijas izotermas uz Pavāru atradnes dabīgā mālu parauga. Adsorbcijas izotermai ir S-veida forma. Desorbcijas izotermas forma ir līdzīga adsorbcijas izotermai. Sorbcijas izotermai raksturīga šaura histerēzes cilpa, kas atbilst II tipa izotermām pēc IUPAC klasifikācijas. S-veida gāzu sorbcijas izoterma ir raksturīga Latvijas illītu saturošiem mālu paraugiem. Slāpekḷa gāzes sorbcijas izotermas uz Pavāru atradnes dabīgā mālu parauga sākumposms ir izliekts, kas liecina par parauga mikroporainu struktūru. Dotais paraugs satur arī vidēja izmēra poras, par ko liecina šaura histerēzes cilpa. Slāpekḷa gāzes sorbcijas izoterma uz Strēḷu atradnes 
mālu parauga, kas parādīta 3.attēlā, būtiski atšḳiras no iepriekš aplūkotās izotermas. Adsorbcijas izotermai arī ir S-veida forma, bet desorbcijas izotermā vērojams raksturīgs pakāpiens relatīvo spiedienu apgabalā $\mathrm{P} / \mathrm{P}_{\mathrm{o}}$ ap 0.5 , kas liecina par attīstītu parauga iekšējo poru struktūru. Izoterma atbilst IV tipam pēc IUPAC klasifikācijas. Šāda tipa sorbcijas izotermas raksturīgas Latvijas montmorillonītu saturošiem mālu paraugiem, kas spēj uzbriest ūdenī.

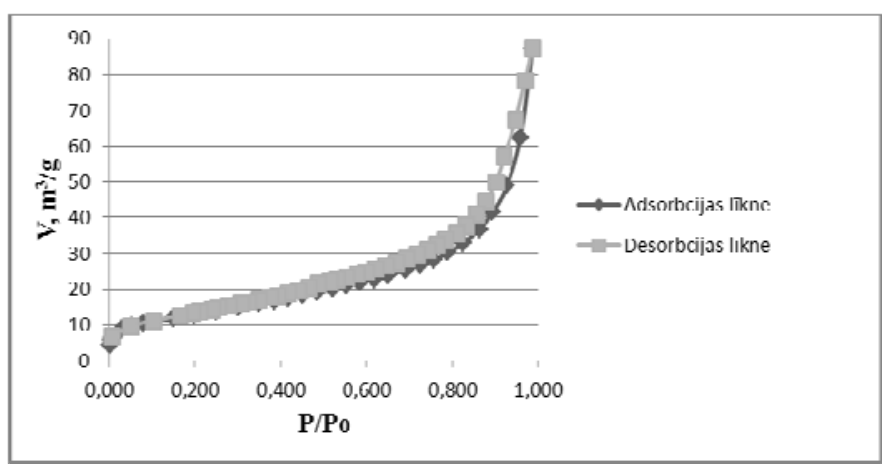

2.att. $\mathrm{N}_{2}$ gāzes adsorbcijas-desorbcijas izoterma uz Pavāru atradnes mālu parauga.

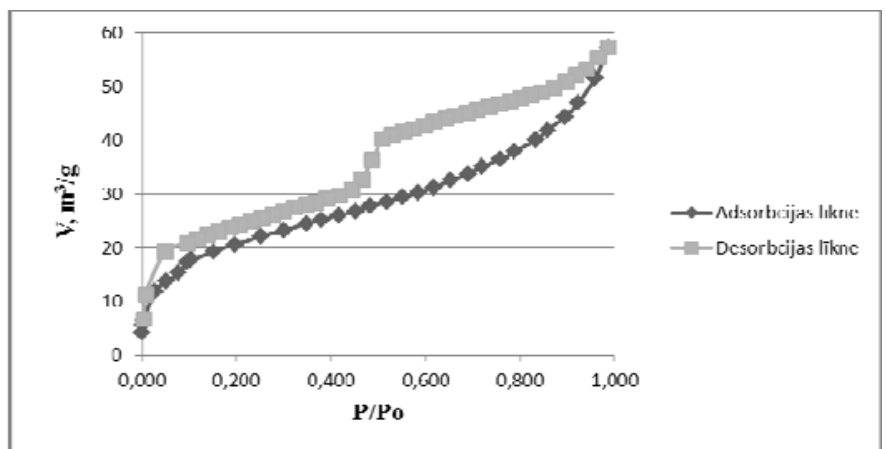

3.att. $\mathrm{N}_{2}$ gāzes adsorbcijas-desorbcijas izoterma uz Strēḷu atradnes mālu parauga.

Slāpekḷa sorbcijas izotermas uz Strēḷu atradnes dabīgiem un termiski apstrādātiem mālu paraugiem ir parādītas 4. un 5. attēlā. Jāatzīmē, ka visos paraugos adsorbcijas un desorbcijas procesi nav atgriezeniski un ir novērojamas histerēzes cilpas. Histerēzes cilpas ir šauras, kas liecina, ka paraugos ir vidējā izmēra aizpildītas poras. Izotermu forma praktiski nemainās termiskās apstrādes laikā, mainoties adsorbcijas lielumiem.

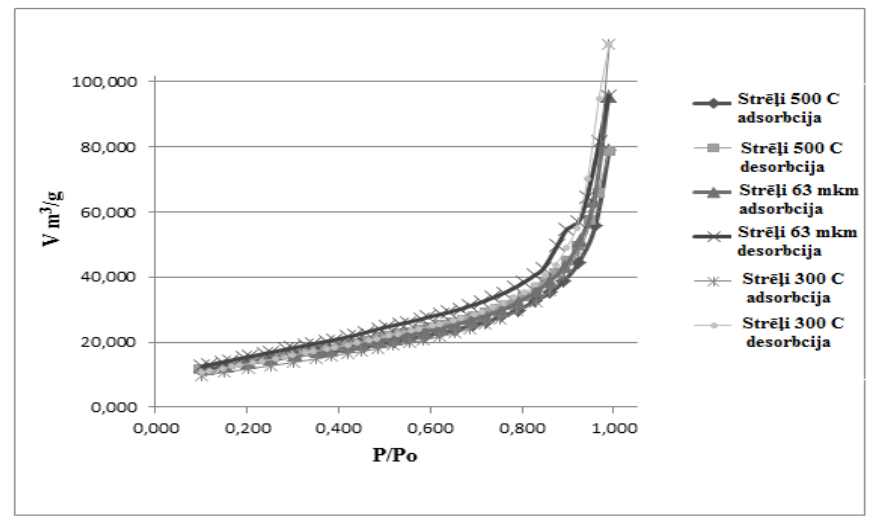

4.att. $\quad \mathrm{N}_{2}$ gāzes sorbcijas izotermas neapstrādātiem un termiski apstrādātiem 300 un $500^{\circ} \mathrm{C}$ temperatūrā Strēḷu atradnes mālu paraugiem.
Slāpekḷa gāzes maksimālā sorbcija uz termiski apstrādātā Strēḷu atradnes mālu parauga $300^{\circ} \mathrm{C}$ temperatūrā ir augstāka, nekā uz dabīgā Strēḷu atradnes mālu parauga (skat.4.att.). Izotermā ir novērojama daudz platāka histerēzes cilpa, jo $300^{\circ} \mathrm{C}$ temperatūrā no mālu parauga izdalās fizikāli saistīts ūdens un atbrīvojas vidējā izmēra poras (mezoporas). Slāpekḷa gāzes maksimālā sorbcija uz termiski apstrādātā Strēḷu atradnes mālu parauga $500^{\circ} \mathrm{C}$ temperatūrā samazinās, salīizinot ar dabīgo un $300^{\circ} \mathrm{C}$ apstrādāto Strēḷu atradnes mālu paraugiem. Paaugstinot apstrādes temperatūru no 300 līdz $500^{\circ} \mathrm{C}$, no parauga izdalās ķīmiski saistīts ūdens un notiek alumosilikātu dehidratācija.

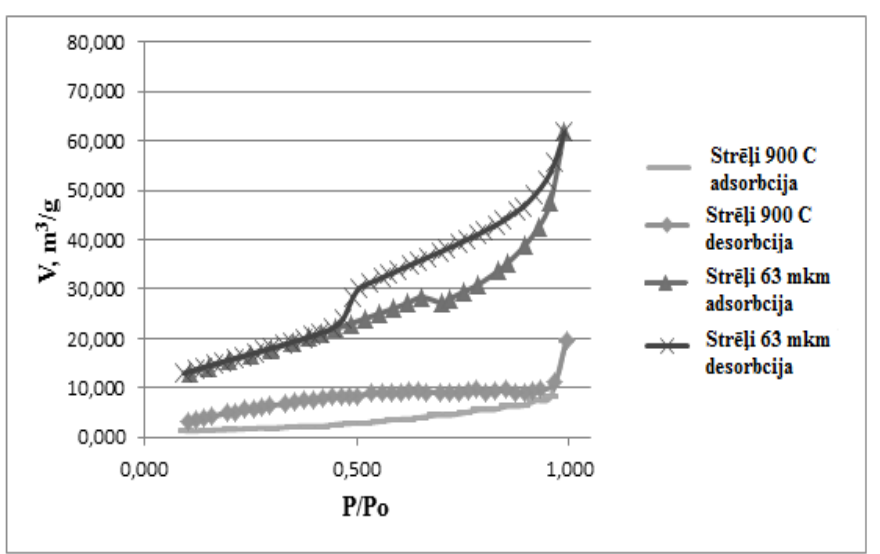

5.att. $\mathrm{N}_{2}$ gāzes sorbcijas izotermas uz neapstrādātiem un termiski apstrādātiem $900^{\circ} \mathrm{C}$ temperatūrā Strēḷu mālu paraugiem.

$550^{\circ} \mathrm{C}$ un augstākās temperatūrās sākas fāžu pārejas un saķepšanas process. Tā rezultātā samazinās sorbcijas spēja un mālu īpatnējā virsma. $800-900^{\circ} \mathrm{C}$ saķepšanas procesi kḷūst intensīvāki, un sorbcijas spēja, kā arī īpatnējā virsma ievērojami samazinās (skat. 5.att.).

Slāpekḷa gāzes sorbcijas izotermas uz Tūjas atradnes dabīgiem un termiski apstrādātiem mālu paraugiem ir parādītas 6. un 7. attēlā.

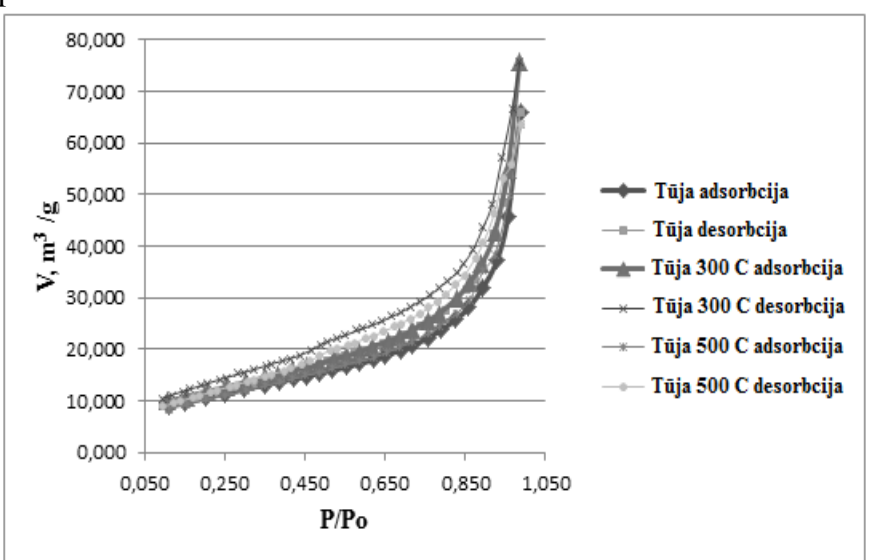

6.att. $\mathrm{N}_{2}$ gāzes sorbcijas izotermas uz neapstrādātiem un termiski apstrādātiem 300 un $500^{\circ} \mathrm{C}$ temperatūrā Tūjas atradnes mālu paraugiem.

Slāpekḷa gāzes sorbcijas izotermas uz Tūjas atradnes dabīgiem un termiski apstrādātiem mālu paraugiem pēc formas ir identiskas izotermām uz Strēḷu atradnes mālu paraugiem. 


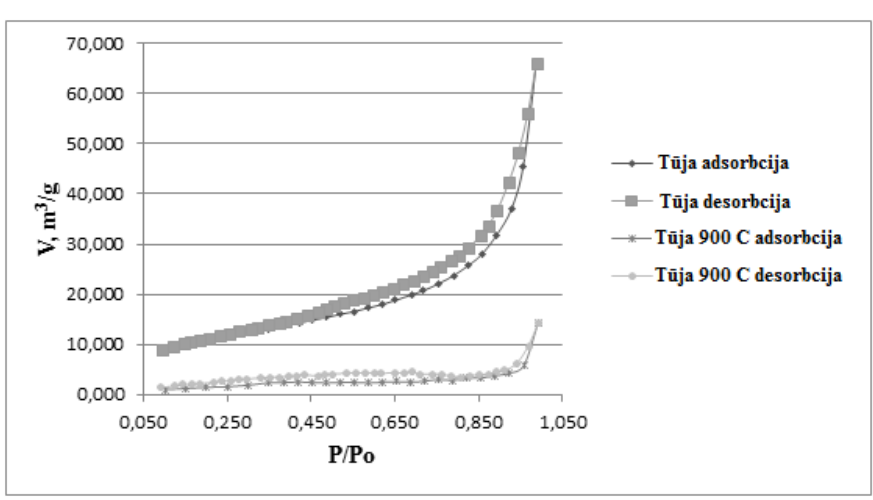

7.att. $\mathrm{N}_{2}$ gāzes sorbcijas izotermas uz neapstrādātiem un termiski apstrādātiem $900^{\circ} \mathrm{C}$ temperatūrā Tūjas atradnes mālu paraugiem.

Slāpekḷa gāzes sorbcija uz Tūjas atradnes mālu parauga, kas apstrādāts $900^{\circ} \mathrm{C}$ temperatūrā ir zemāka, nekā uz dabīgā Tūjas atradnes mālu parauga, jo notiek saķepšanas procesi, noārdās mālu parauga struktūra, kā rezultātā sorbcijas spēja un īpatnējā virsma ievērojami samazinās (skat.7.att.). Līdz̄igas likumsakarības ir iegūtas ar Ceplīšu un Pavāru atradṇu termiski apstrādātiem mālu paraugiem.

Izmantojot adsorbcijas izotermas, pēc BET metodes noteikta adsorbenta īpatnēja virsma. Pētīto mālu paraugu īpatnējās virsmas lielumi ir apkopoti 3.tabulā.

\section{TABULA}

DABĪGU UN TERMISKI APSTRĀDĀTU LATVIJAS MĀLU PARAUGU İPATNĒJĀS VIRSMAS LIELUMI

\begin{tabular}{|c|c|c|c|}
\hline \multirow[b]{2}{*}{$\begin{array}{c}\text { Parauga } \\
\text { apzīmējums }\end{array}$} & \multirow[b]{2}{*}{$\begin{array}{c}\text { Daḷiņu } \\
\text { izmērs, } \mu \mathrm{m}\end{array}$} & \multicolumn{2}{|c|}{ Apstrādes apstākḷi } \\
\hline & & $\begin{array}{c}\text { Apstrādes } \\
\text { temperatūra, } \mathrm{t} \\
{ }^{0} \mathrm{C}\end{array}$ & $\begin{array}{c}\text { Parauga BET } \\
\text { ippatnējā virsma, } \\
\mathrm{m}^{2} / \mathrm{g}\end{array}$ \\
\hline Tūja & $<63$ & 25 & 38,32 \\
\hline Tūja300 & $<63$ & 300 & 42,76 \\
\hline Tūja500 & $<63$ & 500 & 38,71 \\
\hline Tūja700 & $<63$ & 700 & 34,86 \\
\hline Tūja900 & $<63$ & 900 & 6,69 \\
\hline Strēẹli & $<63$ & 25 & 71,73 \\
\hline Strēḷi300 & $<63$ & 300 & 78,95 \\
\hline Strēḷi500 & $<63$ & 500 & 41,79 \\
\hline Strēḷi700 & $<63$ & 700 & 32,27 \\
\hline Strēḷi900 & $<63$ & 900 & 3,15 \\
\hline Ceplīši & $<63$ & 25 & 48,60 \\
\hline Ceplī̌si 300 & $<63$ & 300 & 49,76 \\
\hline Ceplīši 500 & $<63$ & 500 & 43,56 \\
\hline Ceplīši 700 & $<63$ & 700 & 36,45 \\
\hline Ceplīši 900 & $<63$ & 900 & 6,08 \\
\hline Pavāri & $<63$ & 25 & 52,65 \\
\hline Pavāri 300 & $<63$ & 300 & 52,43 \\
\hline Pavāri 500 & $<63$ & 500 & 48,05 \\
\hline Pavāri 700 & $<63$ & 700 & 46,65 \\
\hline Pavāri 900 & $<63$ & 900 & 7,77 \\
\hline
\end{tabular}

No 3. tabulas datiem redzams, ka, palielinot karsēšanas temperatūru no $25{ }^{\circ} \mathrm{C} \operatorname{li} \mathrm{dz} 900{ }^{\circ} \mathrm{C}$, pētīto mālu paraugu īpatnējās virsmas lielumi iziet caur maksimumu. Piemēram, Strēḷu atradnes mālu paraugu īpatnējās virsmas lielums mainās šādi: palielinās no $71,73 \mathrm{~m}^{2} / \mathrm{g} \quad \mathrm{l} \mathrm{d} \mathrm{z} \quad 78,95 \mathrm{~m}^{2} / \mathrm{g}$ un samazinās līdz pat $3,15 \mathrm{~m}^{2} / \mathrm{g}$, palielinoties karsēšanas temperatūrai līdz $900^{\circ} \mathrm{C}$.

\section{SECINĀJUMI}

1. Pētītas pulverveida Latvijas mālu atradṇu paraugu sorbcijas īpašības un īpatnējā virsma. Mālu paraugi apstrādāti termiski temperatūrās no 300 līdz $900^{\circ} \mathrm{C}$.

2. Noskaidrots, ka, palielinot karsēšanas temperatūru līdz $300{ }^{\circ} \mathrm{C}$, pētīto mālu paraugu sorbcija un īpatnējās virsmas lielumi palielinās, kas ir skaidrojams ar fizikāli saistīta ūdens izdalīšanos no mālu paraugiem un mezoporu atbrīvošanos. Īpatnējās virsmas lielumi ir aprēķināti pēc BET metodes.

3. Palielinot karsēšanas temperatūru no $300^{\circ} \mathrm{C} \operatorname{li} d z 500^{\circ} \mathrm{C}$, mālu paraugu sorbcijas spēja un îpatnējā virsma samazinās, jo sākas fāžu pārejas un organisko vielu izdalīšanās no paraugiem. Temperatūrai paaugstinoties līdz $700^{\circ} \mathrm{C}$, notiek kristāliska saistīta ūdens izdalīšanās un saķepšana.

4. Palielinot karsēšanas temperatūru no $700^{\circ} \mathrm{C} l \bar{i} \mathrm{dz} 900^{\circ} \mathrm{C}$, notiek mālu paraugu saķepšana un ievērojama īpatnējās virsmas samazināšanās.

\section{LITERATŪRAS SARAKSTS}

[1] Sing, K.S.W., Everret, D.H., Haul, R.A.W., et. al. Reporting physisorption data for gas / solid systems with special reference to the determination of surface area and porosity. Pure and Applied Chemistry, 1985, vol. 57, p. 603 - 619. http://dx.doi.org/10.1351/pac198557040603

[2] Lakevičs, V., Bērziņa-Cimdina, L., Ruplis, A., et.al. Sorption properties of Latvian clays and environmental protection survey. In: 7 th International Scientific and Practical Conference Environment. Technology. Resources, Rezekne, Latvia, June 20-22, 2009, Conference materials. Rezekne 2009, vol.1, p.222-227.

[3] Ruplis, A. Sorption and catalytic properties of Latvian clay powders. Colloid and Polymer Science. 2000, vol. 116, p. 48-56.

[4] Ruplis, A. Latvijas mālu sorbcijas īpašības. Latvijas Ķīmijas žurnāls, 1997. $\mathrm{Nr} 2,43 .-47.1 p p$.

[5] Lakevičs, V. Sorption characteristics of Latvian clays. Ph.D. thesis. Riga: Riga Technical University, 2006. $24 \mathrm{p}$.

[6] Lakevich, V., Ruplis, A. Acidic treatment influence on sorption parameters of Latvian clay samples. In: International conference EcoBalt '99, Rīga, Latvia, May 14 -15, 1999, Abstracts. p.78-79.

[7] Lakevičs, V., Ruplis, A. Nīcgales mālu paraugu virsmas raksturojums. In: 40. studentu Zinātniskās un Tehniskās konference. Rīga, Latvija, 26.30.aprīlis 1999. Tēzes, 6.lpp.

[8] Švinka, V., Pētersone, E. Latvijas mālu sorbcijas īpašǐbas un to izmantošana ūdens attîrīšanai. Latvijas Ķīmijas Žurnāls, 1994, Nr. 3, 280. lpp.

Vitalijs Lakevičs Dr. chem. (2006), leading researcher at Riga Technical University, Material science and applied chemistry faculty, Institute of General Chemical Engineering. He is a member of the Latvian Material Research Association from 2008. From 2011 he is a docent at the Institute of General Chemical Engineering of RTU. Main fields of study are synthesis of sorbents, sorption properties of inorganic materials, biomaterials, environmental science and technology. He is the author and co-author of more than 25 scientific publications.

Address: 3/3 Pulka street, Riga, LV 1045, Latvia.

E-mail : vitalijs.lakevics@rtu.lv

Phone:+371 29331348 
Olga Kaplinova B.sc.ing. (2013) at Riga Technical University, Material science and applied chemistry faculty, Institute of General Chemical Engineering.Research interests: Specific surface area and porous structure of illite containing Latvian clays.

Address: 14/24 Azenes Street, Riga, LV-1048, Latvia

E-mail: olga.kaplinova@inbox.lv

Phone: +371 29910192

Valentīna Stepanova Mg.sc.ing., Researcher at Riga Technical University, Faculty of Materials Science and Applied Chemistry, Institute of General Chemical Engineering. Over the last 5 years her scientific interest focuses on the sorption properties of Latvian clays, environmental science and technology. She is the co-author of more than 10 scientific publications. Address: 14/24 Azenes Street, Riga, LV-1048, Latvia

E-mail: stepanv@inbox.lv

Phone: +37129888581

Inga Dušenkova Mg.chem., Researcher at Riga Technical University, Faculty of Materials Science and Applied Chemistry, Institute of General Chemical Engineering. Since 2008 Ph.D student in Riga Technical University. Research interests: environmental science and technology, clays nad clay minerals, their physically chemical and sorption properties. She is the author and co-author of more than 10 scientific publications
Address: Address: 14/24 Azenes Street, Riga, LV-1048, Latvia E-mail: ingadbl@gmail.com Phone: +37129679224

Liga Berzina-Cimdina, Dr.sc.ing., Professor and Head of the Institute of General Chemical Engineering, Director of R. Cimdins Riga Biomaterials Innovation and Development Centre, and Head of the Department of General Chemical Engineering at RTU, Faculty of Material Science and Applied Chemistry. She manages study program specializations for: Chemistry and Technology of Biomaterials, Environmental Engineering, General Chemical Technology. Scientific work of Prof. L. Berzina-Cimdina includes management of international and regional projects (EU, the Balkan countries, Latvia), development of new biomaterials and eco-materials, research of new applications for these materials and research on interaction of materials and biological systems. She is the author of more than 100 scientific publications, author and co-author of 3 patents.

Address: 3/3 Pulka street, Riga, LV 1045, Latvia

E-mail: liga.berzina-cimdina@,rtu.lv

Vitālijs Lakevičs, Olga Kaplinova, Valentīna Stepanova, Inga Dušenkova, Līga Bērziņa-Cimdiṇa. Influence of Thermal Treatment on the Specific Surface Area of Illite-Containing Latvian Clays.

This work experimentally studies sorption of nitrogen on natural and thermally processed samples of Latvian illite clays with a particle size of less than $63 \mu \mathrm{m}$ which originated from 4 deposits - Tūja (Devonian period), Ceplīši and Pavari (Quarternary period) and Strēẹi (Jurassic period). The specific surface of the obtained samples was measured using BET method from low temperature (77 K) physical nitrogen adsorption-desorption, measured by a volume method on the specific surface and measured by a porosity size analyzer Quadrasorb SI (Quantachrome USA).

Optimal conditions of thermal treatment of the natural clay samples were determined. The impact of thermal treatment on natural clay samples was analyzed. It was defined that with the increasing thermal treatment temperature of clay samples up to $300^{\circ} \mathrm{C}$, the specific surface increases, which can be explained by the elimination of the physically bonded water from their surface and the release of mesopores. With the increasing temperature of the clay samples thermal treatment from 300 to $500{ }^{\circ} \mathrm{C}$, specific surface of clay samples reduces which can be explained by the beginning of the phase transition. With the increase of the temperature of the clay samples' thermal treatment from 500 to $700{ }^{\circ} \mathrm{C}$, the specific surface of the samples is reduced significantly because of the release of crystalline bonded water and the beginning of the particle sintering process. With the increase of the temperature of the clay samples' thermal treatment up to $900{ }^{\circ} \mathrm{C}$ there occurs the clay particle sintering, and so their specific surface is the smallest one comparing to the other samples, which were processed at lower temperatures. The obtained results contain important information about specific surface and sorption properties of Latvian clays, serving as an addition to the database of Latvian clay deposits which have not been studied before.

Виталий Лакевич, Ольга Каплинова, Валентина Степанова, Инга Душенкова, Лига Берзиня-Цимдиня. Влияние термической обработки на удельную поверхность иллитсодержащих латвийских глин.

В работе экспериментально исследована сорбция азота на природных и термически обработанных образцах латвийских иллитовых глин с размером частиц менее $63 \mu \mathrm{m}$ из четырех месторождений - Туя (девонский период), Цеплиши и Павари (четвертичный период) и Стрели (юрский период).

Удельная поверхность полученных образцов измерялась по методу БЭТ из изотерм низкотемпературной (77 К) физической адсорбции-десорбции азота, полученных объемным методом на анализаторе площади поверхности и пористости Quadrasorb SI (Quantachrome США).

Определены оптимальные условия термической обработки природных образцов глин. Исследовано влияние термической обработки на природные глиняные образцы. Выяснено, что при повышении температуры термической обработки образцов глин до $300{ }^{0} \mathrm{C}$ удельная поверхность увеличивается, что объясняется удалением физически связанной воды с их поверхности и освобождением мезопор. При повышении температуры термической обработки образцов глин от 300 до $500{ }^{0} \mathrm{C}$ удельная поверхность образцов уменьшается, что связано с началом процесса фазового перехода. При повышении температуры термической обработки образцов глин от 500 до $700{ }^{\circ} \mathrm{C}$ удельная поверхность образцов значительно снижается за счет выделения кристаллически связанной воды и начала процесса спекания частиц. При повышении температуры термической обработки образцов глин до $900{ }^{0} \mathrm{C}$ происходит спекание частиц глины, поэтому их удельная поверхность самая низкая по сравнению с образцами, обработанными при более низких температурах. Полученные результаты содержат важную информацию и дополняют базу данных об удельной поверхности и сорбционнных свойствах образцов еще неизученных месторождений латвийских глин. 